\title{
Konstrukcija ženskog identiteta u poeziji Tina Ujevića
}

\author{
Miodarka TePavČEVIĆ \\ Univerzitet Crne Gore, Filološki fakultet, Danila Bojovića bb, \\ ME-81400Nikšić,migat@t-com.me
}

\begin{abstract}
1.01 Izvirni znanstveni članek - 1.01 Original Scientific Article
Nova prebiranja Ujevićevih besedil so omogočila analizo strukture jezikovnega diskurza o ženski in tudi analizo lingvističnih izrazov vrednostnih stališč o njej. V članku se avtorica posveti analizi ženske identitete, ki v kontekstu širšega diskurza osvetli številne podrobnosti Ujevićevih pogledov na ženske. S tem delom želimo izpostaviti pomembnost in vlogo ženske v njegovi poeziji in odstreti še en del njegove zapuščine. Od njegovih zgodnjih pesniških zbirk in rim do bolečih verzov in zrelih od so Ujevićeva dela prežeta $\mathrm{z}$ vilami in drugimi mitološkimi boginjami, ljubljenimi in nedosanjanimi ženskami, ki s svojo močjo vseprisotnosti skupaj ustvarijo glas ženske. Definiranje tega harmoničnega zvoka številnih žensk se kaže kot neobhodni del naracije in nosilec sporočila poezije.

New readings of Ujević's texts have made it possible to analyse the structure of the linguistic discourse about women as well as the linguistic expressions of value-based attitudes toward them. In the paper, the author deals with an analysis of female identity, which in the context of the wider discourse illuminates many details of his views towards women. With this work we would like to point out the significance and role of women in Ujevićs poetry and reveal another segment of his poetic legacy. From his earliest poetry collections and initial rhymes, to the painful verses and mature odes, Ujević's poems are full of numerous fairies, mythological goddesses, women who were loved and those with unfulfilled dreams, who through the power of omnipresence together constitute the voice of one woman. The defining of this harmonic voice of many women appears as an indispensable part of the narrative and the carrier of the poetic message.
\end{abstract}

Ključne besede: Tin Ujević, hrvaška literatura, ženska identiteta, ljubezen

Key words: Tin Ujević, Croatian literature, female identity, love

Jer meni treba moćna riječ, jer meni treba odgovor, i ljubav, ili sveta smrt Tin Ujević: Svakidašnja jadikovka

\section{Uvod}

Univerzalnošću raspona i koordinatama pjesničkog svijeta, ostvarenom sintezom modernog i klasičnog poetskog iskustva, rafiniranom formom, originalnom i sugestivnom pjesničkom vokacijom poezija Tina Ujevića dostiže europsku razinu. Svoj 
duh je bogatio na tekovinama udaljenih kultura, filozofiji religija i poetika i bio otvoren otkrićima i stremljenjima ljudskog duha (Sang Hun Kim 2016: 103-110). Ovaj neobični boem podredio je svoj život pjesničkom stvaranju i stvaralačkoj slobodi. Klasik izvorne umjetnosti, strastveni esteta - skeptik i eklektik, erudita i zavjerenik mistike i tajne, pjesnik ljubavi i smrti, uspio je da ih pomiri u ljepoti kao njihovom jedinstvu i najvišoj emanaciji ljudskog duha. Tin nije bio jedinstven, bio je "pjesnik lirskih susreta i misaonih katarzi, otvoren svim doslusima od Sapfe do Verhaerena, senzibilan na stare i nove, estetske i misaone, naboje — od drevne Kine do evropskog modernizma, unanimista i futurista" (Šimundža 1982: 240).

Život i djelo Tina Ujevića bili su u velikoj mjeri uvjetovani ne samo obilježjima njegovog mnogostranog duha nego i drugim moralnim i duševnim osobinama koje su tvorile njegovu sveukupnu ličnost. Ujević je bio izuzetan po svemu - po svojim shvatanjima i životu, po svojoj viziji svijeta i moralnim načelima. On je veliki revolucionar u kome su sjedinjeni unutarnja snaga, emocionalnost, misaona zrelost, virtuoznost umjetnika, spiritualnost i kozmički osjećaj svijeta. Njegov je život gorak, dostojanstven, složen i nedokučiv. On je sazdan u znaku pobune protiv urođenih etičkih i estetičkih normi koje su sputavale misaoni i svaki drugi razvitak čovjekov, probijajući tako nacionalne okvire da bi postao svjetski pisac (Marković 1962: 483, 485-486).

Skoro svi kritičari se slažu da je riječ o izuzetnoj ličnosti hrvatske kulture koja se svojim građanskim statusom, ponašanjem, svojim idejama, cjelokupnim životom, izuzela od sredine u kojoj živi, ograđujući se od drugih ljudi ironijom, intelektualnom superiornošću, ignoriranjem svakidašnjice i normi građanskog života, boemskom ekstravagancijom. "Jedinstven u tom smislu u hrvatskoj književnosti prve polovice XX. stoljeća - i po tome nikome sličan - Ujević je bio nošen ovim strujama: parnasovstvo i simbolizam (u prvoj fazi stvaranja), te ekspresionizam, simultanizam, kubizam, futurizam i nadrealizam (u kasnijim fazama)" (Stamać 2004: 77).

Ujević je univerzalni pjesnik svjetskih dimenzija, čiju poeziju karakterizira savršenstvo forme, misaonost, bogatstvo slika i zvonka muzikalnost. On "pripada onoj rijetkoj vrsti umjetnika koji, čim nešto dodirnu... odmah to i ožive. Bio pustolov i fanatik svoje umjetnosti, ponosni usamljenik osuđen da živi dvostrukim životom - kao legendarni boem pred ljudima i kao kontemplativni sanjar u svojoj samoći. Tako je bio razapet njegov genije koji je nosio teret duha i života. Ovaj svetac poezije uvijek se sudarao sa stvarnošću, pa opet nije postojao poklonik očajanja pred njom... Sve je kod njega s onu stranu uma u nadzemaljskim jezama i proročanskim grčevima, jer je bio alhemičar-pjesnik koji je od kamena pravio plamen" (Gajević 1988: 280).

${ }^{1}$ Pjesničko djelo hrvatskog pjesnika Tina Ujevića pobuđivalo je u proteklim desetljećima veliku pozornost kulturne javnosti i književne kritike koja je bila motivirana ne samo literaturnim razlozima nego i potrebom da se pronikne u smisao jednog života koji je po mnogo čemu bio izuzetan - vidjeti detaljnije Gajević 1988; Goranović 2008: 17, 19, 335-344; Sabrana djela Tina Ujevića 1963-1966: 383-458, 457-484. Ljiljana Šarić i Ellen Veit napisale su bibliografiju radova o Tinu Ujeviću od 1981. do 2003. Bibliografija radova o Ujeviću do 1967. objavljena je u Sabranim djelima 1967 (Šarić 2006: 153-158). 


\section{Jezičko vrjednovanje - Ujevićev model žene}

Tin Ujević nije uobičajen pjesnik, njegovo djelo je i danas više nego aktualno, a dijelom i neistraženo. Uzimajući u obzir dosadašnje unekoliko zanemareno proučavanje Ujevićevog djela s lingvističkog aspekta ${ }^{2}$, bavit ćemo se analizom ženskog identiteta koji na širem diskursnom planu osvjetljava mnoge pojedinosti njegove vizije žene. Nova čitanja Ujevićevih tekstova ${ }^{3}$ omogućila su da se analizira struktura jezičkog diskursa o ženi, kao i lingvistički izrazi vrjedonosnih stavova prema njoj. U radu ćemo identificirati, izdvojiti, klasificirati i analizirati ovaj leksički sloj koji se odnosi na koncept žene. Promatrat ćemo semantička i sintaksička sredstva u jezičkom valoriziranju.

Ovim radom želimo istaknuti značaj i ulogu žene u Ujevićevoj poeziji i tako upotpuniti još jedan segment njegove pjesničke zaostavštine. Od najranijih zbirki i početnih rima do bolnih stihova i zrelih oda, kroz Ujevićeve pjesme prodefilovale su mnogobrojne vile, mitološke boginje, voljene i nedosanjane drage, koje svojim snagom sveprisustva zajedno čine glas jedne žene. Definisanje tog unisonog glasa mnogobrojnih žena javlja se kao nezaobilazni dio narativa i nositelj određene poetske poruke.

Istraživanja i rasprave o ženi, njenim osobinama, stereotipima, predstavama, uvijek su pobuđivali veliku pozornost i kontroverzna mišljenja. Ne samo u laičkim već i u znanstvenim raspravama o ženi često se pod maskom racionalnog i objektivnog diskursa skrivaju emocije i predrasude. O ženama su ispisani milijuni stihova i napisane najljepše ljubavne pjesme, stvarani romani, naslikane najljepše slike, snimani filmovi... Priča o ženama zbog toga nema ni početka ni kraja, uvijek će ostati nedorečena i nedokučiva... jer takva je i žena (Milosavljević/Klem 2008: 3).

Koje su najvažnije značajke Ujevićeve ljubavne poezije? Gdje se nalaze njena duhovna ishodišta i uporišta, njeni stvaralački uzori i ideali? ${ }^{4}$ Što je žena? U pjesničkoj prozi Poluistine kaže: "Jedna magična žena prođe, i pretvori se u bezbroj drugih. Gužva žena: jedna ima podbradak njezin, druga boju obraza. A svima je zajednička prolaznost" (SD:1963-1966, 378). No, Tin, na drugom mjestu navodi: "A u malom broju žena našao sam na Izvanrednu Iskru koja bi trebala biti red reda. No jedina o kojoj bih mogao govoriti (s velikim Ž) bila bi ta koja bi, žena, ukinula spol i sačuvala samo psihu" (SD:1963-1966, 235). Dakle, u ljubavi je tražio spiritualnu zanesenost, a nalazio je bol i san, pa je te tragove nastojao potisnuti u sebi i pronaći luku u drugim stvarima - poeziji, rodnom mjestu, prostranom Kristu.

Počevši od prvih stihova iz Ujevićeve razvojne faze, preko glavnih ljubavnih pjesama, susrećemo se sa mnogobrojnim ženskim figurama i simboličkim dimenzijama žena. Samo u naslovima, uočili smo veliki broj pjesama koje izravno ili

\footnotetext{
${ }^{2}$ Vidjeti o tome radove: Tomić 1981; Peti 1981; Težak 1981; Selak 1992; Šarić 2007.

${ }^{3}$ Primjere smo ekscerpirali iz Sabranih djela 1963-1966; kao i zbirke Odabrane pjesme 1957. U radu ćemo koristiti skraćenice SD, OP.

${ }^{4}$ Na poetiku Tina Ujevića utjecali su u prvom redu Dante, Petrarka, suvremena kritika pominje više imena od srednjovjekovnih trubadura do modernih romantičara, ekspresionista, dadaista, unamunista, futurista, nadrealista, kao što su: Vijon, Marulić, Po, Hajne, Nerval, Bodler, Rembo, Malarme, Verlen, Niče, Matoš, Verharen, Apoliner, Vitman, Valeri, Breton (Goranović 2008: 26).
} 
neizravno sadrže ime neke ženske osobe, pa su tako mnoge od njih naslovljene kao: Naše vile (OP, 28); Molitva Bogomajci za rabu božju Doru Remebot (OP, 38); Žene među kraljicama (OP, 48); Misao na nju (OP, 52); Vivijani (OP, 56); Žene (OP, 60); moja Vjerenice (OP, 67); Razapeta Afrodita (OP, 168); Čari žene (OP, 228); Vrućica od žene (OP, 229); Doživljaji zatočene Sfinge (OP, 343); Savremene gospođice (OP, 335).

Ujević je u poeziji stvorio najcjelovitiju misao i viziju o ženi, kao složenom, teško saznatljivom, trošnom, pa ipak vječnom biću. Na tom putu pisac je uvijek ostao vjeran percepciji njezina lika. On o njoj govori i s poštovanjem i s prezirom, slavi je i proklinje, ona je i radost i patnja, i zagonetka. Analizirajući Tinov odnos prema ženama u pjesmama, zapažamo varijacije od ljubavi i strasti koje očituju nešto mistično i zabranjeno do čistih, petrarkističkih kanconijera o doživljaju ljubavi kao vrhunca sreće.

Ujevićev opšti model obuhvata ženske realne (denotativne), konceptualne (pojmovne) i formalne (izražajne) komponente. On je sastavljen od kategorija jezičkog, književnog i stilskog modela, koji se međusobno prožimaju obrazujući složeni sustav odnosa. ${ }^{5}$

U pjesnikovom viđenju žene javljaju se tri fundamentalna odnosa - identičnost, sličnost i različitost. Žena se dovodi u vezu sa drugim živim bićima, mrtvim predmetima i prirodnim pojavama.

\begin{abstract}
Ja te tako motrim kraj smeđih portala / kao neko biće iz Višega Svijeta (SD, 55); Sveta k'o regina Helena iz rake (OP, 28); Ona je u podzemlju duše čudesni fantom skriti (OP, 231); Ona je kao zvono što tromo u vidike kuca (OP, 231); Ona je kamen zavitlan u kolobare vode (OP, 231); Ona je šedrvan što kroz tišine muca (OP, 231); Ona u podrumu bića kao žižak svjetluca (OP, 231); Ona je riječ kakva se nije progovorila (OP, 231); Ti si pod lukom prozora doživljaj snene mašte (SD, 143); K’o zora ruža u docnome inju (OP, 37); Roso, Mistična Ružo (SD, 63); Ti si nevina rosa (SD, 84).
\end{abstract}

Sa druge strane, u piščevom poimanju žene dolazi i do izražaja i raznolikost, nesklad između sadržaja i forme, riječi i djela.

Ona je ponos i gubitak vida, i ljubav nema koprene ni stida (SD, 55); Nad mojim mrakom sijevaju tek tvoje, / tuđinska ženo, samilosne oči (OP, 123); A ti što smiješkom vrijeđaš ropsku patnju (OP, 135); Al ona žena idealna / što nemir duše žudi strti / ima u jami oka stalna / duboki, kruti oganj smrti (OP, 131); Ti si u vijencu snova sva dobrostiva, / budi da čini ruku širiš, o Radostiva, / budi da tajnu suzu briššs, o Žalostiva (SD, 73).

Ova sredstva imaju značajnu ulogu u skretanju pozornosti čitatelja i stvaranju negativne ili pozitivne slike referenata. U sintaksi vrjednujućih struktura u određenim usporednim elementima otkrivaju se asocijacije koje izjednačavaju ženu sa drugom pojavom i pri tome, kada je riječ o negativnom ili pozitivnom vrjednovanju, daju joj veći stupanj negativnoga/pozitivnoga.

Značenje je jedno od važnih obilježja u njegovoj poeziji. Ujevićev model se odlikuje dvojnom semantikom, koju čini značenje žene, a odnosi na njenu ulogu u društvu, i drugi - žena kao značenje. Zapravo žena se promatra u trokutu denotacija (živo biće), signifikacija (pojmovna predstava o ženi) i nominacija - jezički

\footnotetext{
${ }^{5}$ Detaljnije o ovim koncepcijama vidjeti rad Tošović (2005: 15-111).
} 
izraz (Tošović 2015: 28). Postoji nesklad između broja ovih kategorija, pa smo kod Ujevića zabilježili najveći broj denotata - različitih naziva za ženu:

književnica (OP, 28); banice (OP, 28); muze (OP, 28); Gospa (OP, 34); žena (OP, 34); moja Vjerenica (OP, 67); Gospo, rajska bebo (OP, 84); tužna vila (OP, 86); djevojko iz mog kraja (OP, 146); Muze (OP, 146); djevojke (OP, 218); krčmarica (OP, 294); Majko (SD, 65); Ubio je ženu, ubio je taštu (SD, 149); djeve (OP, 28); Drage rajne seste i drage, Marulova seja $i$ Dubravka, Cvijeta (OP, 28); Mučenica Zrinska Katarina, književnica, duše pobožne i jake (OP, 28); srce Amazonke (OP, 28); Jelena, mat sina (OP, 28); Sučanica gdje je Kosara, kći kralja (OP, 28); Neda i Sokolica, sjajni niz koralja (OP, 28); Koso Vivijane (OP, 33); Beta (OP, 34); Marija i Eva (OP, 34); poćerko Trećeg Boga Parakleta (OP, 36); Hjeronima (OP, 36); Vidosava (OP, 36); Marijo, zvijezdo bijelih naraštaja (OP, 38); sveta žena Dora Remebot (OP, 39); Sveta Madona naše svjetske Muze (OP, 39); Marija i Klara (OP, 68); Meluzina ili Anđelika (OP, 69); Ravijojla, bijela ljuba (OP, 73); Bogorodice (OP, 80); Tina nije mrtva, ona samo spava (OP, 81); Beatriće (OP, 86); pramajka Eva (OP, 108); Lijepa ženska imena, Renala, Ofelija, Cecil, Agrafena, i Jelena, i Klelija, imena svijetlih laži, i ljubavi i mirisa, imena bola, draži, i stobojnoga irisa (OP, 115); plašljiva Madona (OP, 119); slavna Izabela (OP, 128); Izoldo, cvijete bijelih ruku (OP, 135); Ksenija (OP, 142); Ines de Luna (OP, 146); Sapfo (OP, 173); Šeherezada (OP, 195); odliva se iz kalupa vrelih žena tvojega kova, / žena kôšto Belkis, Lilit, Tamar nisu (OP, 194); Julijeta (OP, 300); meni ne liči društvo lijepih djevojaka, / ali Ti, Frijo ili Afrodito, Vječita Sanjarijo, / razgali se kao nimfa samoće (OP, 155); Ne žudim za Matom Hari ni gospođom Pompadour (SD, 144).

U analiziranim pjesmama bilježimo primjere nominacije žena iz tradicionalnog, ali i religijsko-mitološkog svijeta, primjere nepoznatih, zvučnih ženskih imena. Ono što uočavamo jeste da se u njegovoj poeziji o ženi ne govori samo općenito, već se javljaju određene potkategorije pojma žene, koje ovise o društvenom, srodničkom ili generacijskom statusu. Tako se kao referent javljaju navedeni pojmovi. Oni su determinisani socijalnom pripadnošću, srodnošću, uzrastom, izgledom, zanimanjem, intelektualno-emocionalnim sklopom i sl. Imenice u Ujevićevom diskursu o ženi denotiraju konkretne (žena, majka, djevojka), ali i apstraktne pojmove (muza, vila, nimfa). Osvrnemo li se na Ujevićev opus uočavamo "mnoštvo sličnih činova imenovanja od kojih se mnogima prizivaju slavni ženski likovi iz povijesti svjetske književnosti” (Drenjančević 2018: 31).

U Ujevićevoj poeziji žena ima pozitivne i negativne osobine, ali se ponekad javlja i bez kvalitativne eksplikacije. Semantički sadržaj određuje se pomoću najfrekventnije leksike i leksičkih jedinica, koji imaju određenu vrijednost, dok sintaksička struktura podrazumijeva specifična semantičko-stilistička sredstva. Valoriziranje znači "pripisivanje ili odricanje kvaliteta, ili istovremeno i jedno i drugo" (Starčević 1998: 412). Jezičko vrjednovanje realizuje se izravno ili neizravno. Pozitivna ili negativna atribucija karakteristika je izravnog procjenjivanja, koje se ostvaruje pomoću punoznačnih riječi, odnosno sintaksema. Neizravna ocjena izražava se također kroz određenu leksiku, koja se ostvaruje kroz asocijacije, komparacije i druga stilsko-jezička sredstva (Starčević 1998: 414).

Markeri pozitivnih osobina su češći, a odnose se na:

- fizička svojstva

O ženo, s tijelom čudnim kao samet (SD, 56); gizdavih ljepota (OP, 28); idealna usta (OP, 36); miris ljepote stuji u toj kosi (OP, 108); njene su usne pune slatke varke (OP, 108); njene su ruke drhtave i žarke (OP, 108); skladna ramena $(\mathrm{OP}, 146)$; ženstvene oči $(\mathrm{OP}, 66)$; 
- umna svojstva

a duh je u tvom bogu majčinstvo žensko samo, / ti si nevina rosa (OP, 168); a mila žena (nježna vila, svila) / neće me više draganom i pažem (OP, 121); žena idealna (OP, 131); Ti si $u$ vijencu snova sva dobrostiva (SD, 73); duše pobožne i jake (OP, 28);

- Životne vrline

Svaka je od vas rođena da vlada, / i da za prijesto pruži mliječno dijete (OP, 48); Te divne žene ognjevite rase njegovana lica pokrivaju velom (SD, 190);

- socijalne vrijednosti

I bolje da me ne znadu pod časnim imenom moje majke i sestre (SD, 197).

Primjećujemo da su negativna vrjednovanja leksema, kao i tipovi njihovih leksičko-semantičkih grupa manje zastupljeni od leksema sa pozitivnim predznakom. Markeri negativnih osobina se uglavnom odnose na intelektualna i duhovna stanja, kao u primjerima:

njeno lice, tašta sfinga ispod maske (OP, 228); Ta čarobnica truje svoje eligzire (OP, 231); nebrigo žene (OP, 125); Ceri se drolji Isidori (SD, 195); Mrzim te oči mračne i duboke, I kunem te noge pred kojima padam, / $i$ altar tijela gdje u prahu ležim (OP, 108); zbog jedne žene ja propadam $(\mathrm{OP}, 120)$; kletva jedne žene (OP, 134); bludnica $(\mathrm{OP}, 68)$.

Pisac pažljivo bira leksiku, stilematičnim postupcima na sintaksičkom planu stvara vrjednosni leksički sloj. Ponekad dolazi do spoja minusa i plusa, odnosno negativnog i pozitivnog:

Je li ona mačka? hijena? avet? žena? / Amblem, mašta, uspomena, / strašna vizija s međa Nubije ili Libije? / Ona je najčudnije biće s Nila, / i nijedna žena, u mulju rijeke, pod brdom pijeska (OP, 343); košuto plaha (OP, 135).

Na ovaj način traži se aktivno angažiranje čitatelja u potrazi za rješenjem - pitanje ne pretenduje na konačnost forme niti obavijesti, već svaka riječ otvara beskrajno polje mogućnosti - što je žena u Ujevićevoj viziji?

\section{Tajne i istine o ženama u Ujevićevoj poeziji}

Smatrajući ženu tajanstvom života, on je uzdiže među kraljice i doživljava je kao apsolutnu ljepotu, san i priviđenje: jer vi ste žene među kraljicama (OP, 49); Jer ti si došla s druge strane svijeta (OP, 113). Žena je pretvorena u smisao života. Ona je uzvišena, nedostižna i neuhvatljiva, iako prema njoj duh neprestano stremi: Božanske žene, sva ljepota svijeta, i lavska gordost i plahota srne (OP, 48). Kod Ujevića se svi problemi slivaju u jedan, u problem ljubavi, ali mistično shvaćene ljubavi: Božanska ženo, gospo nepoznata, / dokle i kamo, mene misliš vući? (OP, 111).

Ujevićevo shvatanje ljubavi i žene prožeto je romantikom, idealizacijom, pa čak i krišćanskim misticizmom. On pristupa ženi kao majci i madoni. Uvija je u plašt daljine i čuda kao nešto tajno, nepoznato i transcendentno: I preklinjem te: Nepoznata reci, / kakva te tuga iz daljine draga, i još mi reci, gdje si, što si, ko si? (OP, 111); Što si? Zagonetka. (OP, 34). Ona je povod za rascvat njegovih emocija i misaonosti; uselila se u njegovu dušu i preobrazila u ideal: ljubljena ženo, ko si 
ti da jesi, / luđačku ljubav suvišno je kriti (OP, 63). Željena, a nedostižna žena, o kojoj se neprestano sanja, postaje izvor patnje i pesimizma: Molitvi mojoj cilj, ikona, a mojoj mašti san i bajka (OP, 110). I pored toga, Ujević je u iluzijama o njoj našao jedno spokojstvo i pribježište od životne zbilje.

Ujević nije pristajao na kompromise. Htio je idealnu sreću, neograničenu slobodu i potpunu ljubav. Ali pošto je idealna sreća nedostižna, a ljubav "ropstvo po definiciji”, morao se odreći obje da bi sačuvao bar težnju za slobodom, jer je za njega ljubav i alem, sitnica u rijetkoj zbirci korund vrijedan ko gradska mitnica (SD, 144), ali i ljubav je pizma (SD, 148).

U ranoj poeziji ljubav se idealizira do apsoluta, koja zauvijek ostaje nedostižna, a u čudesnim zbirkama visokog simbolizma Lelek sebra i Kolajna ljubav je dominantna tema. U Leleku sebra data je prouhovljena varijanta ljubavne poezije iskazana sonetima posvećenim idealnoj ženi - Vivijani, Dori, Remobot, Mariji, Klari, Anđeliki, Beati. Već ustanovljena težnja za apsolutnim svojstvena je brojnim stihovima Leleka sebra, u kojima je iskazana čežnja za idealnom ljubavi i potreba za obraćanjem Bogu. Žena je za njega svetinja pred kojom se klanja, a čitav život bježi od tog ideala žene i sklanja se u okrilje poezije. U Kolajni žena je povod da se ljubavno osjećanje preobrazi u ljepotu života i umjetnosti, a Ujević je štovao ljepotu kao božansko, što je izražavao i pjesnički i esejistički. Ljubavna mistika potječe iz rastrzanog pjesničkog stanja i odatle prelazi u ljepotu iskaza.

Problem žene kod Ujevića je komplikovan i protivurječan. Ona je i milosrdna, puna ljubavi i praštanja, ali i lakoumna, grešna, pohotna i koketna. Žena je i jedno kontradiktorno biće, prinuđeno da svoje slabosti prikriva glumom, jer ona ponor i plamen usred oka nosi (OP, 108); ona je ponos i gubitak vida (OP, 47). Ona je, s jedne strane, Marija, milosrdna i milostiva, očiju punih ljubavi i milošte, gotova da prašta i tješi; s druge strane, Eva, grešnica lakoumna i lakomislena, gotova da učini ma šta da bi se njena riječ ispunila, koketa:

Žena na mom pragu. Druga je pred kućom,/ Svuda, svuda žena. Marija i Eva, / avaj! Bivam grešnik. A tom ploti vrućom / kao ljuti samum i ledena Neva / struji očaj te me stvori palikućom; / doznah da mahnitah, kada ljubav pjevah (SD, 159).

Pjesnik je svjestan polivalentnosti ženske figure, pa pjeva o dvije žene - sanjao sam jutros san o dvije žene, / to su dvije duše kroz dvije razne zjene, / jedna gleda bistro, a druga kroz mene. / Koja od njih može da me strasno krene? / Oči pune magle očaraše mene (OP, 294).

Za njega više vrijedi nevina i čista žena, kojoj je sve zemaljsko pojmljivo, možda i privlačno, ali ne i toliko da bi mu se podala i odala; žena kojoj je ljubav Bog i majka njegova:

Ljubav je Bog, ne Dzeus ni Sabaot, / I zato neka je sanak blagoslovljen, / I neka pada drač i trnski plot; / Majka je Bog, ne Dzeus ni Sabaot, / I nek me čuje kada vapim slomljen / Za rabu Božju Doru Remebot (OP, 234).

Sudeći prema njegovim sopstvenim priznanjima, ovaj pjesnik nije se odrekao ljubavi zato što se razočarao u ženu, već i zbog toga što su ga ljubavna osjećanja iscrpljivala i egzistencijalno ugrožavala. 
Ja sam opazio, da nikada ne osjećam tako kao ljubeći...; ali da od ranjene ljubavi ne mogoh ni hodati, dakle da njena nesreća ne razboljevaše samo moje osjećanje, nego i moju misao... Ljubav sama, i ona baš najviše, pri samoj svojoj pojavi razdire čovjeka tjelesnom mukom i nelagodnošću, nekim nemirom što ne dozvoljava da se sjedi, da se stoji, da se leži, da se radi, no goni čovjeka po poljima, po livadama, po morima, daleko od sebe, u nemir što kida i lomi. A teško meni, ja sam pored svih užasnih kriza kojima je naše vrijeme obilovalo, ja sam pored i povrh svega toga bio ranjen u ljubavi. Popljuvan, išćuškan, premlaćen, izmučen, pedepsan i prebit u neprovredivoj, u neoskrvljenoj ljubavi, i to mi je donijelo patnje kakve se bojah da nije čovjek prije mene iskusio. (SD 1963-1966: VI, 260-261, 287-288)

Ovakve ljubavne patnje mučile su Ujevića u mladosti, kada mu je uzavrela duša bila obuzeta i drugim (političkim, moralnim i socijalnim) strastima i idealima. Kasnije, kada je sazrio, on mijenja mišljenje i o ljubavi i ženi, što se može zaključiti na temelju njegovih riječi:

Žene služe čemu i sve ostalo; spletkama, pa me već godinama nije ni u kakvom društvu... Ima u ženi toliko ružnih stvari koje su za prirodu sasvim dosljedne, ali ne za duh, jer upućuju na život. Zato bih i ženu htio zadržati samo u sferi duha, u iluzornoj sferi... ja prigovaram ženi ono što prigovaram i čovjeku; da je dio zoologije, bolje životinjske antroplologije, koja se nije prekalila u sekreciji suprematizma... Ljubav nije slobodna, ona je ropstvo po definiciji... Moja je primitivna filozofija bila: ima lijepih žena, krasotica, ovim treba pokloniti ljubav, voljeti ih. Kasnije sam promijenio: ljubav je bolest. (SD 1963-1966: XIV, 142; VI, 149-150; V, 83)

Žena je u njegovoj poeziji simbol sa širokim spektrom značenja. Kroz nju se posredno saopštava njegov odnos prema brojnim drugim problemima života. "I baš zato što se odnos prema ženi beskrajno komplikuje, jer implicira, u sferi potisnutosti i sublimacije, najkompleksnije odnose pesnika prema svetu, životu i sopstvenom biću" (Pavletić 1964: 13-14). Ona se javlja kao simbol, dio društva i individua, pa u njegovoj poeziji dolazi do izražaja simbolički, socijalni, individualno-psihološki položaj žene.

U mnogim pjesmama primjećujemo da Ujević samo u sferi duhovnog vidi mogućnost ljubavi. Zato pokušava da sve shvati duhovno, suprotstavljajući se tjelesnom. Ovako spiritualizovana vizija ljubavi je neostvariva, a samim tim i tragična, jer nijedna žena nije mogla da se saživi sa ulogom idealne žene: Božanska ženo, unuko visoke / pramajke Eve, pred tobom sam Adam, / $i$ jer te volim, ja od tebe bježim (OP, 108). A kad je on pokušavao da je spusti na zemlju, da je vidi i doživi kao plotsko, erotsko biće, tome se suprotstavljao njegov san o ženi kao čežnji, bogomajci i idealu ljubavi (Pavletić 1959: 413), jer kako pjesnik kaže: ti si ona za koju mene rodi majka (OP, 110), ali sve ćemo još doživjeti, sve osim ljubavne sreće, sve, osim srdačnih laži (SD, 145).

U njegovim stihovima iz kasnije faze stvaranja nalazimo religiozna raspoloženja, zagonetnost i dijaboličnost žene, za čijom se čednošću žudi i pored plotske žudnje. Jer ona je demon, strast, grijeh, pakao, pohota, simbol zla, pijanstvo misli i čula: ona je nagon nijemi požudan slasti slobode (OP, 231); ko hladna mana misao me rosi na njezin pokret (OP, 108); krvav demon želje, opsjela je Žena (OP, 229). Zato je novija lirika Ujevićeva obilježena ljubavnim jadom koji ništi sve oko sebe, jer ga izaziva pogibeljna žena - Kada danas, srušen, nemam porodice, / kad ne sreh na valu istinite ljube; / preklinjem te, reci, o Bogorodice, / čemu tvojem Sinu sve tragične trube? (OP, 80). Pjesnikov stav prema ženi nedvojbeno je promjenljiv - $\mathrm{u}$ 
stihovima iz kasnijeg perioda ljubav nije više magična, eros postaje znak zla, ona je čas Himera (pjesma Siromaški put), čas hijena i vampir (pjesma San uskrsava sablasti), čas groteskna utvara (̌̌enska spodoba što pleše po zici $\mathrm{SD}, 250$ ), čas prolazna i uzaludna (pjesma Ukleta djevojaštva). Zato se kao protivteža ovoj ženi, u njegovom duhu i poeziji javlja sveta žena koja je inkarnacija subjektivnog ideala ljepote, pa i religioznog apsuluta. Zahvaljujući tome, ljubavno osjećanje je sve manje čulno i spiritualno, a sve više mistično, zato ona postaje snoviđenje žene (OP, 98).

Zagonetni Ujević dok se oprašta sa ženom kao "velikom obmanom prirode", kao fantazijom Ti si ona koje nema, a ja sam onaj koji nije ovdje (SD, 64), nastavlja potragu za "Ženom idealnom" na jedan drugačiji način, pa pjeva meni se čini da je Svemir, ili Nirvana, ona prava Žena. / To je barem moja žena, moja zaštitnica. I Ne kažem paganski: Muza. (SD, 150). On je poistovjećuje sa svemirom, to je žena "novog kova", žena koja će postati "đerdan snova". Tako se slika žene iz slavne tradicije i kulturne povijesti seli u svemir budućnosti.

U mnogim njegovim pjesmama žena je mistificirana, nestvarna, viđena samo u pjesnikovim snovima. Ujevićeva ljubav je vrlo nejasna: ni plotska, ni čulna, ni idealistička. Plaši se žene kao obmane, pjesnik pati odričući se svega, zagledan narcisoidno u sebe. "Čeka se i moli i zove žena. Nestvarna, nevidljiva, žena iz sjećanja, žena iz vizija, žena u bunilu osama crtana po zidovima svijesti kao freska, nadzemaljske ljepote, čistoga tijela i duše. Žena - duh. Žena - ideja. Žena - religija stvaraočeva, spasiteljica, njegovateljica, žena - lijek od zla" (Goranović 2008: 304)

Ja te tako motrim kraj smeđih portala / kao neko biće iz Višega Svijeta (OP, 112); Možda te vidjeh u dalekoj slici / u kolutima tamjana i slavlja / ili na kakvoj taštoj razglednici (OP, 152); Njoj kojoj ne znam Imena, / sva hvala za moju luku u prostranom Hristu. (OP, 165).

To je žena viših sfera koja ne silazi na zemlju, i živi u čistim predjelima pjesničkog sna. Kada je vizije dozovu u pjesnikovu dušu, ona je ovdje da je osvijetli, da ozrači mističnu svečanost patnje, da bude čudesna kao kap svjetlosti u oku, tužni refren molitve, čuvar duše od grijehova zemaljskih, neizliječena ljepota i patnja koja rađa, čuva i brani jedan novi svijet. Ona je u ovim pjesmama mistična snaga koja pokreće čitav jedan svijet pjesničkih visina. Ona je sve, nepoznato, ljubav ljubavi, san sna, i više od toga:

Božanske žene, sve ljepote svijeta, / i lavska gordost i plahota srne, / kroz vaše čari uzvišene cvjeta / u plave dane, i u noći crne. / I kada stopom punom svetog mira / budite zemlji ritam svih otkrića, / slutim vas srcem plamenim svemira, / slutim i ištem tajnu vaših bića. / Božanske žene, što u snu i slavi / čekate zoru pravednih oltara, / pred vašim likom koljeno se savi / a srce, zvučni plamen, već izgara (OP, 48).

Tin bježi od tih slatkih varki i obmane jer ja te volim, ja od tebe bježim $(\mathrm{OP}, 108)$ i sanja o idealnoj ženi. Ipak, čim pomisli na senzualnost te žene, ponovo se vraća suzdržanosti i pita se šta ćemo mi pjesnici kad ne budemo voljeli žensko tijelo, I kad ne budemo dragali prirodu kao ženu (SD, 172).

U poznatoj pjesmi Molitva bogomajci za rabu Božju Doru Remebot Ujević spaja lik žene majke sa svojom vizijom Madone sa čijih je usana popio prve bajke. I u ljubavnim i u sinovskim osjećanjima Ujević je težio da senzibilnost prenese u sfere idealističke spiritualnosti, da u temama o ženi ispovijeda produhovljene 
svoje, u samoći ćelije proživljavane snove o veličini - čednosti i nevinosti ljudske prirode, koje nemilosrdno prlja ružna java. Zato je žena u Ujevićevim pjesmama “oganj duševnih emocija”. Pred njom je pjesnik i malen i nemoćan i slab, i velik i snažan, pred njom i moli i plače i žali se i otuđuje se, pred njom pada i vaskrsava, brižnog, svetačkog izgleda, ali ona je snaga i bura u pjesmi: snaga koja ruši samo sebe, koja lomi i satire (Goranović 2008: 305):

S krivom il s pravom - ridam: pašću, pašću / od jedne hijene što mi grudi kida, / od jedne žene s dušom i sa strašću. / Ona je ponos i gubitak vida, / a ja je žudim slašću ili čašću, / i ljubav nema koprene ni stida (SD, 55); Pred njenim likom da se skromno klekne / u slavu bola i u slavu snova / kao pred neki živi Jeruzalem. / I da se plače, i da se vjera rekne. / I svaki uzdah bude Vita Nuova, / A svaka suza dragi sjajni alem (OP, 38).

Mit i san o ženi, s jedne strane, i čvrsta realnost, s druge strane - put je kojim se pjesnik kreće. Tin piše u feljtonu Žena u dušinom ogledalu: "Naći višu ženu sa dubokim srcem bio bi ideal, ali je u životu sve puno ograničenja i traži odricanja" (SD, 1963-1966, 327). Nekada je u slikanju žene bio pravi racionalista, nekada strasni emocionalista, ponekad flegmatični posmatrač, pa i vizionar maštovitosti. A zapravo je bio sve, jer kako je sam jednom prilikom rekao "nosim u sebi više od jednog čovjeka" (SD 1963-1966, XIV, 38). Ta mnogostrukost se ispoljavala u njegovoj poeziji i viđenju žene u njoj.

\section{Zaključak}

Ujevićeva ljubavna poezija je kao more - obilato tajnama, bremenito iznenađenjima, ustalasalo vidljivim i nevidljivim strujanjima, čudesno u svim smjerovima. Uvijek se doživljava drugačije i ne iscrpljuje se.

Kao da se u njemu odvijao sukob mističara i pjesnika, pa je nastojao da pomoću jezika izmiri mistično i pjesničko nadahnuće. On je u jeziku tražio istovremeno sredstvo za izražavanje ljepote, ali i jemstvo da se sačuva od ljepote, koje se smrtno bojao. Slutio je da apsolutna ljepota, koju doziva jezikom svoje poezije, zahtijeva i apsolutno davanje, samoodricanje.

Idealnog čovjeka, pa i idealnu ljubav tražio je izvan sebe. U ljubavi tražio je smisao života, izlaz iz tuđine, samoće i očaja.

Stvarnost njegove ljubavi, njene čistoće i njene vrijednosti bila je sva u njemu... Čistoću žene on sam stvara i čuva... Tijelo je svemu tome davalo one oblike, one momente, koji su značili borbu, apstinenciju, odricanje... (Zorić 1962: 11).

Idealnu ženu tražio je u čitavom nizu žena. Žena je sintaza životnog i apsulutnog - ona je majka i sestra, i Bogomajka, i prinčipesa; ona je carstvo vila, majka ideala, svetkovina dlijetu i kistu, ona je ljubljeno dijete, ikona, san i bajka. Žena je bezimena, nepoznata i kao takva pjesnička opsesija. Ali žena je i neposredni referent koja je jezičkim sredstvima diskursa istaknuta u prvi plan. Ujević je posebnu pozornost poklanjao jezičkom oblikovanju lika žene. I semantički sadržaj valoriziranja žene, kao i lingvistička sredstva kojima se izražavaju su raznovrsni.

Pažljivije zagledanje u ženske figure u Ujevićevoj poeziji kao autonomnog entiteta u poetskom diskursu otkriva pjesnikove promjenljive stavove o ženama. 
Te žene su evoluirale od usnulih djeva, prinčipesa, preko moćnih boginja, do žene kao najranljivije individue, ali fatalne i mistične. Ako pogledamo dinamiku razvoja književnog modela u njegovoj poeziji, primjećujemo da taj model krase dva polariteta - apolonsko i dionizijsko, prošlost i sadašnjost, strast i majčinstvo. Taj dualitet se odslikava u ženi koja je istovremeno i krotka i zla, boginja i smrtnica.

Veličina Ujevićevog pjesničkog majstorsta nalazi se u činjenici da kompleksnu temu sagledavanja ženskog identiteta, koja se kreće od nevine do demonizovane žene, on ni na koji način ne nameće čitateljima kao kanon u svom pjesničkom diskursu. Pjesnik je samo afirmira i daje čitateljima da proniknu u nju i potraže odgovore na složena pitanja poimanja žene u njegovoj poeziji.

\section{IZVORI}

Tin UJEVIĆ, 1963-1966: Sabrana djela (sv. I-XVII). Ur. Dragutin Tadijanović. Zagreb: Znanje.

--, 1957: Odabrane pjesme. Ur. Gvido Tartalja. Beograd: Prosveta.

\section{BIBLIOGRAFIJA}

Dragomir GAJEVIĆ, 1988: Tin Ujević u jugoslovenskoj književnoj kritici. Zagreb: Grafički zavod Hrvatske.

Ivana DRENJANČEVIĆ, 2018: Ujevićeva Kolajna tekstualnih dugova. Književna smotra 189/3, 25-34.

Sang Hun KIM, 2016: Odjeci kultura Dalekog istoka u djelu Tina Ujevića. Književna smotra 48/1, 103-110.

Milivoje MARKOVIĆ, 1962: Zaverenik bola i lepote. Uvod u razmišljanja o poeziji Tina Ujevića. Putevi 5, 15-24.

Ljubisav MILOSAVLJEVIĆ, S. Valerija KLEM, 2008: Žene koje su menjale svet. Novi Sad: MK Panonia.

Vlatko PAVLETIĆ, 1959: Evokacija pred spomen-pločom Tina Ujevića. Izraz 11-12, 405-415.

- -, 1964: Srpski i hrvatski pisci XX veka. Beograd: Prosveta.

Mirko PETI, 1981: O jeziku Ujevićeva pjesništva. Croatica: prinosi proučavanju hrvatske književnosti 11/12, 219-246.

Ante SELAK, 1992: Pjesmom pjesniku (metodski ogledi o Ujevićevoj poeziji). Zagreb: Školske novine.

Ante STAMAĆ, 2004: Tin Ujević o stanju duha dvadesetih godina. Dani hrvatskoga kazališta 30/1, 75-84.

Zoran STARČEVIĆ, 1998: Lingvističko vrednovanje žene i struktura diskursa u poslovici i reklami. Srpski jezik 3, 409-425.

Ljiljana ŠARIĆ, 2007: Modernistička jezična svijest u Ujevićevom stvaralaštvu. Zadar: Croatica et Slavica Iadertina.

- -, 2006: Modernistički aspekti Ujevićević proznih zapisa: Montparnasse. Fluminensia $18 / 2,133-158$. 
Drago ŠIMUNDŽA, 1982: Odrazi vjere i nevjere u hrvatskoj književnosti: Tin Ujević vječno traženje Boga. Crkva u svijetu 17/3, 240-276.

Stjepko TEŽAK, 1981: Otkloni od književnojezičke norme u pjesničkom jeziku Tina Ujevića. Croatica: prinosi proučavanju hrvatske književnosti 11/12, 293-305.

Novo TOMIĆ, 1981: Apsulutna žena u poeziji Tina Ujevića. Osvrt na Kolajnu, Lelek sebra i Pjesničke proze. Croatica: prinosi proučavanju hrvatske književnosti 11/12, 307-321.

Pavle ZORIĆ, 1962: Kritički eseji. Titograd: Grafički zavod.

\section{OBLIKOVANJE ŽENSKE IDENTITETE V POEZIJI TINA UJEVIĆA}

Z ozirom na dosedanje nekoliko manj prisotno preučevanje Ujevićevega dela z jezikoslovnega vidika smo se v članku posvetili analizi ženske identitete, ki v širšem diskurzu osvetljuje številne posebnosti pesnikove vizije ženske. Nova prebiranja Ujevićevih besedil so namreč omogočila analizo strukture jezikovnega diskurza o ženski in tudi analizo jezikoslovnih sredstev, ki izražajo vrednostna stališča o njej. V delu smo identificirali, izdvojili, razvrstili in analizirali leksiko, ki se nanaša na koncept ženske. Ugotovljena je raznovrstnost tako na ravni semantične vsebine vrednotenja ženske kot tudi na ravni lingvističnih sredstev. Če preverimo dinamiko razvoja književnega modela v njegovi poeziji, opazimo, da ga določajo dvojnosti - apolonska in dionizijska, preteklost in sedanjost, strast in materinstvo. Vse to se odraža tudi v ženski, ki je hkrati prijazna in hudobna, boginja in smrtnica. Veličina Ujevićevega pesniškega mojstrstva pa se odraža $\mathrm{v}$ dejstvu, da avtor bralcu ne vsiljuje kompleksnih tem ženske identitete, ki segajo od nedolžne do demonizirane ženske. Pesnik bralcem omogoča vpogled vanje in jih spodbuja $\mathrm{k}$ iskanju odgovorov na kompleksna vprašanja zaznavanja ženske v njegovi poeziji. 